\title{
PCOS Patients Needs Much More than Just Pills from Doctors
}

\section{Anita Mani}

Director, GIFT IVF center, Infertility, Royal Infirmary, Maidstone Hospital, Sharoe Green Hospital, Leeds university Hospital, Barnet Genera, UK

*Corresponding author: Anita Mani, Director, GIFT IVF center, Infertility, Royal Infirmary, Maidstone Hospital, Sharoe Green Hospital, Leeds university Hospital, Barnet Genera, UK, Tel: +919446475033; E-mail: anitadane@gmail.com

Received date: Apr 13, 2016; Accepted date: May 20, 2016; Published date: May 30, 2016

Copyright: () 2016 Mani A. This is an open-access article distributed under the terms of the Creative Commons Attribution License, which permits unrestricted use, distribution, and reproduction in any medium, provided the original author and source are credited.

\section{Introduction}

The discussions by doctors at a local gynecological conference, suggest a strong Apathy towards patients suffering from polycystic ovarian syndrome (PCOS). PCOS has always been an interesting subject to me, so I make it a point to attend and take part in several PCOS related panels in medical conferences.

It is quite evident from all the researches that life style modifications like diet, Exercise and weight reduction play a vital role in the longterm management of PCOS [1]. As the patients are prone to anxiety and depression, psychological assessment is crucial, along with the physical treatment and dedicated counselors can make a big difference in the outcome of the treatment [2].

Quite often, it has been observed that in allopathy, while treating the PCOS women, their psychological problems are not taken into consideration.

The role of pharmacological agents is quite minimal in treating PCOS. All the major gynecological societies have issued guidelines recommending only occassional use of progesterone to induce periods, maximum of up to three or four times in a year [3]. But contrary to the guidelines, around the world, millions of girls/women suffering from PCOS are being overloaded with COC (combined oral contraceptive pills) and insulin sensitizers like metformin, which has critical side effects $[4,5]$. New research on micro biomes and PCOS suggests deleterious effects from COC on the bacteria in the gut [6]. The safety of duration of metformin administration during pregnancy and its effectiveness is still not established [7].

In a recent OBGYN conference, I pointed out the necessity of an integrated approach towards treatment involving counselors, dietitians, physical trainers and cardiovascular risk assessment. But many of the doctors disapproved and were happy to continue with only medicines. It was also shocking to me that only very few doctors among the audience were conducting blood sugar check for their PCOS patients, in spite of the fact that PCOS women comes under high risk group for diabetes. The metabolic disorder sequelae like cardiovascular, endometrial cancer and diabetes risks are not taken into account by many doctors and they prefer to use short cut methods for the treatment.

Let us look at the journey of the life of a PCOS girl. She visits her pediatrician or GP at 12 years with irregular, prolonged and heavy periods after menarche. At around 16, she gets referred to a gynecologist, for the same recurring problem. Soon a series of dermatology consultation commence for acne, acanthosis nigricans (Darkpatches behind neck) and Hirsuitism. She regularly visits salon for waxing and may have lasers/electrolysis done. Once married and settled, (which is often difficult due to obesity, social isolation and aggressive nature) the next couple of years may have to be spent in the waiting halls of infertility clinics. A good chunk of the monthly salary goes to Clomiphene, gonadotropins, IUI etc. Lucky few gets their Laparoscopic drilling done successfully and get pregnant [8]. Some of them have their IVF/ICSI done with infertility specialist. (who is equally stressed out and extremely busy) Whether the procedure is a success or failure most of their savings are spend. Even after conceiving, the risk of miscarriage is so high that pregnancy with single /twins /triplets can often end up in miscarriages or premature deliveries. These women are also more prone to gestational diabetes and time and again have to visit a feta- maternal specialist and keep their babies in NICU [9]. Sadly, those who cannot bear all the stress, succumbs to anxiety or depression and many a times end up under the care of a psychiatrist [10]. Most of them would have visited a dentist, as they are likely to suffer from gingivitis [11]. Some unlucky women will even have to consult a gastroenterologist, as the risk of IBD is also high [12]. As the middle age sets in, chances of diabetes are elevated and the diabetologist/physician is their new friend [13]. Drastic steps like bariatric surgery for morbidly obese women are not rare any more [14]. A visit to Cardiologist becomes mandatory, when the long toll on endothelial dysfunction and lack of estrogen after menopause adds up to a vessel block [15]. Rheumatologists are not spared as arthritis is, of course a part of chronic inflammation [16]. This sums up as to why the specialist needs to learn about PCOS. (I may not have enough space to write about acupuncture/Chinese medicine specialist, dietician, physical trainers and counselors, but they actually do make a difference and may avoid many of the above visits [17].

Our profession demands lot of care and compassion. It is high time we come out of this apathy, as we hold the key to the long-term health of all these PCOS girls. It is our responsibility to make them understand the long-term risks and avoid the huge pandemic disaster that is waiting in the form of obesity and other PCOS consequences.

The author Dr. Anita Mani is a practicing infertility specialist from south India with special interest in PCOS.

\section{References}

1. Norman RJ, Davies MJ, Lord J, Moran LJ (2002) The role of lifestyle modification in polycystic ovary syndrome. Endocrinol Metab 13: 251-257.

2. Deeks AA, Gibson-Helm ME, Paul E, Teede HJ (2011) Is having polycystic ovary syndrome a predictor of poor psychological function including anxiety and depression? Hum Reprod 26: 1399-1407.

3. Hickey M, Higham JM, Fraser I (2012) Progestogens with or without oestrogen for irregular uterine bleeding associated with anovulation. Cochrane Database Syst Rev 9: CD001895.

4. Halperin IJ, Kumar SS, Stroup DF, Laredo SE (2011) The association between the combined oral contraceptive pill and insulin resistance, dysglycemia and dyslipidemia in women with polycystic ovary syndrome: a systematic review and meta-analysis of observational studies. Hum Reprod 26: 191-120. 
5. Lidegaard $\varnothing$, Nielsen LH, Skovlund CW, Skjeldestad FE, Løkkegaard E (2011) Risk of venous thromboembolism from use of oral contraceptives containing different progestogens and oestrogen doses: Danish cohort study, 2001-9. BMJ 343: d6423.

6. Savage DC (1977) Microbial ecology of the gastrointestinal tract. Annu Rev Microbiol 31: 107-133.

7. Vanky E, Stridsklev S, Heimstad R, Romundstad P, Skogøy K, et al. (2010) Metformin versus placebo from first trimester to delivery in polycystic ovary syndrome: a randomized, controlled multicenter study. J Clin Endocrinol Metab 95: E448-455.

8. Gjønnaess H (1994) Ovarian electrocautery in the treatment of women with polycystic ovary syndrome (PCOS). Factors affecting the results. Acta Obstet Gynecol Scand 73: 407-412.

9. Roos N, Kieler H, Sahlin L, Ekman-Ordeberg G, Falconer H, et al. (2011) Risk of adverse pregnancy outcomes in women with polycystic ovary syndrome: population based cohort study. BMJ 343: d6309.

10. Himelein MJ, Thatcher SS (2006) Polycystic ovary syndrome and mental health: A review. Obstet Gynecol Surv 61: 723-732.

11. Özçaka Ö, Ceyhan BÖ, Akcali A, Biçakci N, Lappin DF, et al. (2012) Is there an interaction between polycystic ovary syndrome and gingival inflammation? J Periodontol 83: 1529-1537.
12. Mathur R, Ko A, Hwang LJ, Low K, Azziz R, et al. (2010) Polycystic ovary syndrome is associated with an increased prevalence of irritable bowel syndrome. Dig Dis Sci 55: 1085-1089.

13. Moran LJ, Misso ML, Wild RA, Norman RJ (2010) Impaired glucose tolerance, type 2 diabetes and metabolic syndrome in polycystic ovary syndrome: a systematic review and meta- analysis. Hum Reprod 16: 347363.

14. Buchwald H, Avidor Y, Braunwald E, Jensen MD, Pories W, et al. (2004) Bariatric surgery: a systematic review and meta-analysis. See comment in PubMed Commons below JAMA 292: 1724-1737.

15. Sathyapalan T, Atkin SL (2012) Recent advances in cardiovascular aspects of polycystic ovary syndrome. See comment in PubMed Commons below Eur J Endocrinol 166: 575-583.

16. Moran LJ, Hutchison SK, Norman RJ, Teede HJ. (2011) Lifestyle changes in women with polycystic ovary syndrome. Cochrane Database Syst Rev 7: CD007506.

17. Teede H, Deeks A, Moran L (2010) Polycystic ovary syndrome: a complex condition with psychological, reproductive and metabolic manifestations that impacts on health across the lifespan. BMC Med 8: 41. 